\title{
Potential Areas in Poland for Forestry Plantation
}

\author{
Piotr Boruszewski ${ }^{1}$ (D), Agnieszka Laskowska ${ }^{1}$ (D), Agnieszka Jankowska ${ }^{1, *}$, Marcin Klisz ${ }^{2}$ (D) and Marcin Mionskowski ${ }^{2}$ \\ 1 The Institute of Wood Sciences and Furniture, 159 Nowoursynowska St., 02-776 Warsaw, Poland; \\ piotr_boruszewski@sggw.edu.pl (P.B.); agnieszka_laskowska@sggw.edu.pl (A.L.) \\ 2 Department of Silviculture and Genetics of Forest Trees, Forest Research Institute, Sękocin Stary, 3 Braci \\ Leśnej St., 05-090 Raszyn, Poland; M.Klisz@ibles.waw.pl (M.K.); M.Mionskowski@ibles.waw.pl (M.M.) \\ * Correspondence: agnieszka_jankowska@sggw.edu.pl; Tel.: +48-225-938-634
}

Citation: Boruszewski, P.;

Laskowska, A.; Jankowska, A.; Klisz, M.; Mionskowski, M. Potential Areas in Poland for Forestry Plantation. Forests 2021, 12, 1360. https:// doi.org/10.3390/f12101360

Academic Editors: Dirk Landgraf and Timothy A. Martin

Received: 15 July 2021

Accepted: 3 October 2021

Published: 7 October 2021

Publisher's Note: MDPI stays neutral with regard to jurisdictional claims in published maps and institutional affiliations.

Copyright: (c) 2021 by the authors. Licensee MDPI, Basel, Switzerland. This article is an open access article distributed under the terms and conditions of the Creative Commons Attribution (CC BY) license (https:// creativecommons.org/licenses/by/ $4.0 /)$.

\begin{abstract}
Plantations have many advantages when compared to natural or semi-natural forests, such as shortening production cycles, the production of wood with specific characteristics, and near-market production concentrations. The intensive development of this form of industrial wood production is practiced all over the world. The wood industry in Poland struggles in recent years, with a large shortage of wood. The deficit of wood has been accumulated for several years and is steadily increasing. One of the possibilities to change this trend can be development of fast-growing trees plantations. The main aim of this study was to determine the potential of land in Poland, which could be used for the cultivation of fast-growing trees plantations. The analyses took into account the area and marginal agricultural land. The potential plantation land areas were determined for poplar cultivar "Hybrid 275" and European larch (Larix decidua Mill.). The results show a possibility to generate a considerable area that can be developed into plantations of fast-growing trees in Poland. According to the analyses carried out for the purpose of this study, with only $5 \%$ use of the sown area and $5 \%$ use of forest lands, as well as the boscage (wooded land and bushy land), it is possible to obtain approximately 0.6 MM ha of land for fast-growing tree plantations. In the case of planting 50\% of these lands with larch and 50\% with poplar, and if a 50\% capacity of the plantation is assumed, it will be possible to obtain nearly $6 \mathrm{MM} \mathrm{m}^{3}$ of wood per year.
\end{abstract}

Keywords: capacity; European larch; fast-growing trees; plantations; plantation area; poplar cultivar "Hybrid 275"; sown area

\section{Introduction}

According to the European Panel Federation (EPF), in recent years, there has been rapid growth in the development of European wood sectors. In 2019, in Poland, $11.7 \mathrm{MM} \mathrm{m}^{3}$ of wood-based panels were produced, which made an $18 \%$ share in the UE market; therefore, Poland has become the second (after Germany)-largest manufacturer in Europe [1]. The strategic value of wood in Poland is confirmed by the fact that the industry based on the processing of this raw material is one of the pillars of the Polish economy. The market share of the forestry-based industry in GDP (gross domestic product) is ca. 1.7\% and is higher than in the EU (about 1\%) [2]. Despite that, the wood-based panels sector still faces serious challenges, especially a limited availability of raw wood. Since 2012, a shortage of wood has been observed for the wood-based panels industry in Poland, reaching 20\%, and the trend is maintained [3]. Raw material shortages are now a widespread problem in the world. It is estimated that the wood deficiency would reach $200 \mathrm{MM} \mathrm{m}^{3}$ and $300 \mathrm{MM} \mathrm{m}^{3}$ in 2025 and 2030, respectively [4]. This is an apparent confirmation of the thesis about the strategic importance of wood as a raw material [5].

One of the possibilities to reduce the shortage of raw material can be creating an outer wood production ecosystem or a sub-ecosystem within forest ecosystems consisting of plantations of fast-growing trees. Already, over one-third of the global wood production comes from plantations [6]. There are different directions of using wood from plantations. 
Initially, the leading direction was the establishment of plantations with the possibility of obtaining wood mainly for energy purposes. There are many local, national and international initiatives to support the development of renewable energy sources [7]. In the past decades, the most important tree species grown in European short-rotation coppices intended as a renewable energy source were willow, poplar and, to a lesser extent, aspen and robinia $[8,9]$. European commercial willow plantations were mainly located in Sweden, the UK, Poland and Germany $[7,8,10,11]$. In Poland, they covered a small area of approx. 6800 ha in 2008 [8] and approx. 5515 ha in 2011 [12]. A steady decrease of willow plantations in recent years in Sweden was observed too [13]. It should be noted that, in Poland, willow wood from plantation crops was grown mainly for energy purposes [12].

The growing deficit of wood, mainly in the wood-based panels sector, forced a change in the policy of establishing and running fast-growing tree plantations. Species intended for this type of purpose should be characterized by appropriate dimensional and qualitative characteristics [14]. Moreover, it was found that, in Poland, among the species of fastgrowing trees, the best prognoses are: poplar (mainly the cultivar "Hybrid 275") and European larch (Larix decidua Mill.) $[15,16]$. When relatively dense spacing $(3 \times 3 \mathrm{~m})$ is used, a very high annual increment is obtained-in the case of larch, up to $14 \mathrm{~m}^{3} \times \mathrm{ha}^{-1}$, and poplars even up to $25 \mathrm{~m}^{3} \times \mathrm{ha}^{-1}$-while, usually, it is $14-20 \mathrm{~m}^{3} \times \mathrm{ha}^{-1}$ [16].

Warmbier et al., [17] pointed to the limited possibilities of using willow wood for the production of wood-based panels. Willow wood can be mainly dedicated for use only for core layers of particleboards, and replacing pine particles $25-30 \%$ with willow particles in the core layer of three-layer particleboards allows obtaining materials with properties that meet the requirements of the appropriate standards $[18,19]$. The wood of willow clones has an approx. $25 \%$ higher density than the wood of poplar clones. The use of wood of willow clones for the production of wood-based materials (especially with lower densities) is recommended to a lesser extent. This is due to the technological aspects and the anticipation of obtaining lower-strength parameters of boards made of higher-density wood, because, during pressing, particles from woods of higher density are less susceptible to compression [20-25]. In turn, the usefulness of plantation poplar and larch wood for the production of wood-based panels was confirmed by the published research results [26,27]. This was also evidenced by the implementation of technology and production of this type of material on an industrial scale in Europe (production based on plantation poplar wood).

Plantation development is a very important aspect for the Polish wood industry, especially for the manufacturers of wood-based panels. One of the most important facts justifying the establishment of plantations is the European context of strategic value of wood in the industry. According to the European Commission, wood is also considered an important source of raw materials for emerging bio-based industries [28]. Similar solutions to those already put in place by one of the leading manufacturers of wood pulp and paper can be successfully adopted by the manufacturers of wood-based panels who require large quantities of medium-size wood. Apart from the large corporations, State Forests National Forest Holding (SFN FH) - the main manager of Polish forests, as well as one of the leading manufacturers of wood-should undertake the production of commercial wood from plantations, which would be in compliance with the global tendency to ease the pressure on natural forests. Plantations of fast-growing trees managed only by SFN FH utilize a small area that currently amounts to 2547.94 ha (equivalent of $0.03 \%$ of total forest land) [29].

The formation of forests on former agricultural land can be the result of a natural secondary progression. Recently, particularly in Europe, that is the result of intentional afforestation. This was the effect of promotion by the European Parliament and of the Council the Regulation (EU) No 1305/2013 [28]. The Regulation established a community aid scheme for forestry measures in agriculture, with the general aim of transforming agricultural lands into forested areas. Parallel to this, due to the increase in the world's demand on wood, extensive research on harvesting wood from fast-growing trees plantations is being carried out [30]. The current trends concern mainly wood harvested from genetically modified trees (GMO) [31-34]. As a result of the insufficient recognition of genetically mod- 
ified materials, ethical aspects and legislation shortages, the wide utilization of wood from genetically modified trees in Europe is presently ineffective [35-38]. Insufficient knowledge in the area of genetically modified species, especially in the utilitarian context, imposes the development of new research directions. Experienced foresters are exceptionally helpful in the breeding of fast-growing trees. The advantages of plantations are not only high productivity but, also, the availability and easy access to highly concentrated and deployed resource of raw materials for the wood industry [39-42].

Plantations of fast-growing trees on agricultural lands have a positive effect on the structure of the soil due to the lack of regular heavy agrotechnical treatment. In a longer perspective, the content of carbon and nitrogen in the soil will increase. This is an additional argument for locating plantations of fast-growing trees on low-class lands for a period of time and subsequently returning to cultivating agricultural crops after resources from the plantation are collected. The periodical usage of agricultural land for plantations of fast-growing trees facilitates the regeneration of overexploited land by improving the soil fertility and, consequently, boosts crop growth. This is due to the factors such as [16]: (I) by penetrating the ground, tree roots crumble the lower layer of soil, (II) the intensity of mineral fertilizing is decreased thanks to plants using nutrients that return into the soil with falling leaves, (III) the organic matter from the forest litter increases the humus layer, and (IV) plantations protect soil against excessive evaporation and erosion.

Agroforestry as a form of plantation of fast-growing trees is widely known and used in Western Europe, Asia and South America. Plantations as such are established on spaces larger than standard plantations, where agricultural and meadow plants are primarily cultivated within the first few years [43]. It is beneficial, as the crop residues left in the rows on the fields additionally fertilize the soil. Moreover, agroforestry may be a link between agricultural plant cultivation and tree plantations. It is estimated that the average annual gain from a poplar plantation in Poland is comparable to that from the production of oil-yielding rape or wheat. Moreover, the production cycles become shorter thanks to advancements in science and technology [44]. Fast-growing trees on agricultural land can achieve high biomass yields with a relatively low input of nitrogen fertilizer and are regarded as efficient nitrogen users [8,45]. Dimitrou and Rutz [7] indicated a number of other, nonproduction benefits resulting from the cultivation of short rotation woody crops (SRC or SRWC). The authors report that this type of coppices helps to improve the water quality; enhance biodiversity; provide ecosystem services, i.e., hunting, beekeeping, water supply and fire protection; mitigate animal diseases between farms; prevent erosion; reduce artificial input materials, i.e., fertilizers and pesticides, and mitigate climate change due to carbon storage.

Recently, in Poland, there has been a noticeable increase of the fallowing and setaside process on agricultural land where the conditions for agricultural productions are unfavorable. Such land accounts for approximately $10 \%$ of the agricultural land [46]. This is caused mainly by a low availability of agricultural production areas, which results from unfavorable natural environment and soil quality [47]. Such land is located in areas where a combination of factors such as unfavorable conditions for agricultural production and unfavorable landscape features (eroded land, steppe formation, rocky ground and moorland) occur. The usefulness of agricultural land is also limited by the anthropogenic influence (land degraded and devastated due to careless human activity). The vicinity of factories, express roads and motorways is an additional factor that adds to the negative agricultural conditions. Agricultural land with unfavorable conditions for agricultural production as the above can be a potential area for plantations of fast-growing trees.

Collecting and processing data on forestry plantations is a common practice introduced in many countries around the world [48-50]. However, due to the lack of unambiguous criteria for classifying certain areas into the category of "forest plantation", it is difficult. The data should be derived from statistically designed inventories of forest plantations or statistics for planted areas reported by planting agencies or appearing in national reports. However, it often comes from many sources, e.g., nursery production, 
seedling distribution, estimates derived from agencies, industries and nongovernmental organizations participating in planting programs [51]. For this reason, each study in this area should be treated as a valuable source of information.

The main purpose of the study was to provide suggestions on the potential possibilities of meeting the demand for raw materials, which is considered to be the main problem of the wood industry. As part of the work, the areas available for the establishment of plantations of fast-growing trees were determined, taking into account the potential to generate wood resources as raw materials for the production of wood-based panels. The knowledge in this area is crucial to meet the needs of the wood industry- more, the woodbased panels industry in Poland is highly competitive. The potential plantation land areas were determined for poplar cultivar "Hybrid 275" and European larch. This work is an original study in terms of the definition of potential areas in Poland for forestry plantation.

\section{Materials and Methods}

In the first part of the work, the current data on the area and stock (taking into account age classes) of fast-growing trees: poplar cultivar "Hybrid 275" and European larch (Larix decidua Mill.) were presented. The data were prepared based on the State Forests Information System (SILP) [29]. The results of the study were presented in the form of maps prepared on the basis of Central Codification Information (COT) obtained from the Department of State Forestry Informatics (ZILP). The COT consists of SILP subsystem tables, excluding the planning system. The selections were made as follows:

1. Fast-growing tree plantations (in SILP, a specific separation is marked), with a poplar or larch in the main layer with a total share of at least $50 \%$.

2. Area lists include the entire surface of the plantation areas that were not reduced by any fraction of a dominant species in the main layer.

3. The thickness of the selected species and not the entire plantation was specified in the thickness records.

The second stage of the research was carried out on the basis of data from the Central Statistical Office of Poland [46,52], and the Agency for Restructuring and Modernisation of Agriculture (ARMA) [53] consisted of an analysis of the structure of agricultural areas in Poland and the average area of agricultural holdings with a division into voivodeships. The adopted size of the assumptions resulted from the willingness to present the possibilities of developing agricultural land with a small and, at the same time, rational use of these areas without significantly limiting their area and importance. According to Zabielski [44], a single plantation should have a minimum area of $5 \mathrm{ha}$. A plantation area cannot be too small if all the cultivation and maintenance are mechanized with the use of special equipment to be cost-effective. Baum et al., [8] reported that the more diverse the surrounding landscape, the more species are able to be established in the plantation. Smaller plantations with longer-edged habitats facilitate species immigration from the surroundings better than larger plantations. Small plantations may increase the regional diversity.

For the purpose of this stage, the following were assumed:

1. The plantation-grown species for the wood industry are poplar cultivar "Hybrid 275" and European larch (Larix decidua Mill.).

2. An analysis of the division of the surveying area and land use in 2016 refers to the specification presented in the characteristics of the agricultural holdings [46].

3. The land shares to be dedicated to plantations:

- not less than $5 \%$ and not more than $10 \%$ of the sown areas, permanent crop areas and forest land and

- not less than $5 \%$ and not more than $30 \%$ of the areas of fallow land, wasteland and other land. 
In the third stage, after indicating a potential area for plantation, the available amounts of alternative raw materials for the wood industry were determined based on the following assumptions:

1. Potential plantation land will be allotted completely for the cultivation of fast-growing trees; assuming a 100\% production capacity of $14 \mathrm{~m}^{3} \times \mathrm{ha}^{-1}$ (annually) for larch and $25 \mathrm{~m}^{3} \times \mathrm{ha}^{-1}$ (annually) for the poplar cultivar "Hybrid 275" and 50\% production capacity from the plantation [16], the production cycle should take 40 years in the case of European larch and 25 years in case of the poplar cultivar "Hybrid 275").

2. Total cover of the plantation with European larch, total cover of the plantation with poplar cultivar "Hybrid 275", 50\% cover with larch and 50\% cover with poplar.

Such extensive research dealing with the potential area for forest plantation has never been undertaken before. In the study, the potential areas in Poland for forestry plantations with the available amounts of raw materials were linked.

\section{Results and Discussion}

3.1. The Area and Stock of Raw Material from Plantation of Poplar Cultivar "Hybrid 275" and Larch (Larix decidua Mill.) in Poland - Current State

The data obtained from the State Forest Information System were imposed on the cartograms presented in Figure 1. The species dominating on the plantations of fastgrowing trees in Poland are poplar and larch, which reach up to $80.29 \%$ of the overall plantation area [29]. In general, Poland is characterized by a low share of the poplar and larch plantations in the total forest areas $(0.026 \%)$. The plantations with poplar as the dominant species or poplar single-species plantations (in the first stage of tree stands) are cultivated on $1156.05 \mathrm{ha}$, while plantations with larch as the dominant species or larch single-species plantations (in the first stage of tree stands) cover 889.7 ha. The highest share of the larch plantation is in Radom RDLP, which is reflected by the natural distribution of this species in Poland, excluding mountainous areas, while poplar plantations occupy the largest area in RDLP Gdańsk and Lublin, which means in the regions with the suitable soils conditions for this species. A nearly complete lack of fourth age class plantations seems to be understandable due to the purpose of the plantations of fast-growing trees characterized by short production cycles. In turn, the lack of plantations in mountain areas is associated with limiting climatic conditions. The total stock on plantations of fast-growing poplar trees (taking into account all age classes) was estimated at about $280,000 \mathrm{~m}^{3}$, of which most are in the third age class, i.e., $190,000 \mathrm{~m}^{3}$, whereas the total stock on plantations of fast-growing larch trees (taking into account all age classes) was estimated at about $160,000 \mathrm{~m}^{3}$, of which most are in the second age class, i.e., $120,000 \mathrm{~m}^{3}$. In 2015, the annual shortage of raw wood only for the wood-based composites industry in Poland, reached the level of around 7.7-11.4 $\mathrm{MM} \mathrm{m}^{3}$ [54]. On the basis of the presented data, it can be clearly stated that the acreage of fast-growing trees (poplar and larch) in Poland is insufficient to eliminate the deficit of wood to a large extent. Therefore, there is a need to increase plantation areas in Poland. 

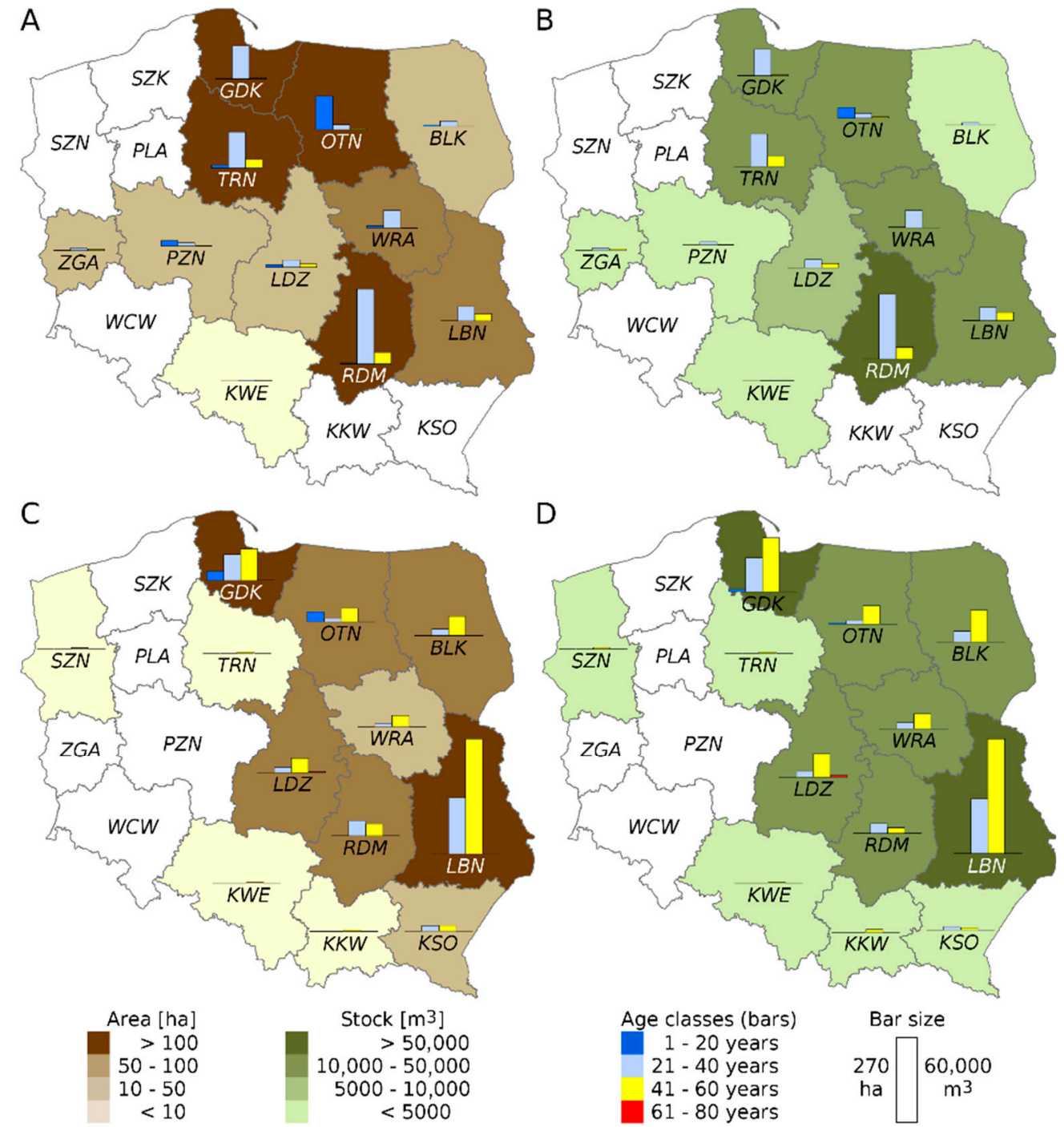

Figure 1. Arrangement of fast-growing tree plantations: $(\mathbf{A}, \mathbf{B})$ larch and $(\mathbf{C}, \mathbf{D})$ poplar in the regional LP Directorates. The carto diagram of the surface and stock (thickness) broken down into age classes (bars) and the cartogram of the total surface (bronze shades, A,C) and thicknesses (shades of green, B,D). In the RDLP without the colours and bars, there is a lack of fast-growing tree plantations. The sizes of the bars are linear. The symbols of the regional names of the LPs are explained in Abbreviations. In addition to the legend: On the left, cartographic explanations (colours RDLP: shades of brown-surface and green-stock). On the right-hand side, explanations for the carto diagrams (the colours of the bars and their sizes). Abbreviations: RDLP-Regional Directorates of the State Forests; BLK-RDLP in Białystok; GDK-RDLP in Gdańsk; KKWRDLP in Kraków; KSO-RDLP in Krosno; KWE-RDLP in Katowice; LBN-RDLP in Lublin; LDZ-RDLP in Łódź; OTN-RDLP in Olsztyn; PLA-RDLP in Piła; PZN-RDLP in Poznań; RDM-RDLP in Radom; SZK-RDLP in Szczecinek; SZN-RDLP in Szczecin; TRN-RDLP in Toruń; WCW-RDLP in Wrocław; WRA-RDLP in Warszawa; ZGA-RDLP in Zielona Góra.

\subsection{The Assessment of the Potential Area of Land for Plantations of Fast-Growing Trees in Poland}

According to the Statistical Yearbook of Agriculture of the Central Statistical Office of Poland [46], in 2016, there were 14.5 MM ha of agricultural land, nearly $99.1 \%$ of which was in good agricultural condition. Of the above-mentioned land, plantations may be established on sown areas or fallow lands. Additionally areas used for permanent crops and permanent meadows can be partially prepared for plantations. A potential area for the plantations of fast-growing trees may also partially consist of forest land, as well as of woody and bushy land. The total area of this type of land was 944,031 ha in 2016 (Table 1). The data concerning the agricultural land and the number of agricultural farms did not include agricultural landowners who do not perform agricultural activity and owners of 
less than 1 ha of agricultural land who perform agricultural activities on a small scale [46]. Taking into consideration the geodesic area of the country, its utilization and the above assumptions, the potential area of land for plantations of fast-growing trees was shown in Table 1 . Assuming only $5 \%$ use of the sown area, it is theoretically possible to obtain, respectively, 531,999 ha of land for plantations of fast-growing trees. If the utilized area constitutes $5 \%$ of the sown area and $5 \%$ of the fallow land, permanent meadows, forest land and woody and bushy land and wasteland and other land, a potential area for plantations of fast-growing trees may even reach almost $0.77 \mathrm{MM}$ ha. If the target assumptions are reached, i.e., the land allotted to plantations of fast-growing trees constitutes $10 \%$ of the sown area, permanent meadows and forest land and $30 \%$ of the fallow land, uncultivated and other land and a potential area for plantations may reach approximately $1.52 \mathrm{MM}$ ha. $\mathrm{Xu}$ and Mola-Yudego [13] analyzed the evolution and location of fast-growing plantations in Sweden for 30 years (for the period 1986-2017). The authors pointed out that willow tends to be planted on higher-productivity agricultural areas and poplar on less-productive lands. On this basis, it can be assumed that establishing poplar plantations on less fertile soils is an opportunity to change the management of the available land. According to the National Agricultural Census, since 2010, 300,000 farmers did not declare agricultural activity on their own farms, which theoretically constituted 447,000 hectares of uncultivated land potentially available for plantations [52]. However, these data do not fully reflect the situation in this kind of agricultural farm. Some of the agricultural areas (of the agricultural farms) were leased by the owners of other agricultural farms without an official contract. According to the data collected for the National Agricultural Census [52], the highest number of agricultural farms that do not carry out agricultural activities was in Ślaskie Voivodeship (31.7\%), Lubuskie Voivodeship (24.4\%) and Małopolskie Voivodeship (20.4\%), while the lowest number of such holdings was in Lubelskie Voivodeship (8.0\%).

Table 1. The potential area of land for the plantation of fast-growing trees in Poland [46].

\begin{tabular}{|c|c|c|c|c|c|}
\hline \multirow{3}{*}{ Land Type } & \multirow{3}{*}{ The Area (ha) } & \multicolumn{4}{|c|}{$\begin{array}{l}\text { The Use of Land for Plantations } \\
\text { of Fast-Growing Trees in Poland (\%) }\end{array}$} \\
\hline & & 5 & 10 & 20 & 30 \\
\hline & & \multicolumn{4}{|c|}{ The Area (ha) } \\
\hline I. Agricultural land area & $14,543,282$ & - & - & - & - \\
\hline 1. In good agricultural condition & $14,405,650$ & - & - & - & - \\
\hline sown area & $10,639,984$ & 531,999 & $1,063,998$ & - & - \\
\hline fallow land & 165,627 & 8281 & 16,563 & 33,125 & 49,688 \\
\hline permanent crops & 393,457 & 19,673 & 39,346 & - & - \\
\hline kitchen gardens & 31,084 & - & - & - & - \\
\hline permanent meadows & $2,698,018$ & 134,901 & 269,802 & - & - \\
\hline permanent pastures & 477,479 & - & - & - & - \\
\hline 2. Others & 137,632 & 6882 & 13,763 & 27,526 & 41,290 \\
\hline II. Forest land as well as woody and bushy land & 944,031 & 47,202 & 94,403 & - & - \\
\hline III. Wasteland & 748,884 & 37,444 & 74,888 & 149,777 & 224,665 \\
\hline Total & $16,236,196$ & 786,382 & $1,572,763$ & 210,428 & 315,643 \\
\hline
\end{tabular}

According to the adopted assumptions, the minimum area for plantation should be 5 ha [44]. An analysis of the data presented in Table 2 leads to a conclusion that agricultural farms meeting the expectations of an average area lower than 5 ha are located in Małopolskie and Podkarpackie Voivodeships. An observation can be made that Małopolskie Voivodeship characterizes the smallest average area of agricultural land per farm, i.e., 4.16 ha [53]. This is due to the fact that only one out of five agricultural farms in this voivodeship does not carry out any agricultural activities; it can be assumed that this is a region where small-sized areas are concentrated. Upon the merger of such lands, they will form an area large enough to be used for the plantation of fast-growing trees. This direction is in line with foreign trends. The need for the cultivation of different tree species 
in small-scale units is indicated [55]. In Sweden, there is a trend towards preferring smaller plantations (below 1 ha) versus large ones (above 10 ha) [13].

Table 2. Average area of land in an agricultural farm in 2020 in Poland [53].

\begin{tabular}{cc}
\hline Voivodships * & Average Area of Land in an Agricultural Farm (ha) \\
\hline Małopolskie & 4.16 \\
Podkarpackie & 4.94 \\
Świętokrzyskie & 5.88 \\
Lubelskie & 7.98 \\
Lódzkie & 7.98 \\
Ślaskie & 8.14 \\
Mazowieckie & 8.77 \\
Podlaskie & 12.55 \\
Wielkopolskie & 14.09 \\
Kujawsko-Pomorskie & 16.58 \\
Dolnoślaskie & 17.29 \\
Oppolskie & 19.16 \\
Pomorskie & 19.62 \\
Lubuskie & 22.29 \\
Warmińsko-Mazurskie & 23.25 \\
Zachodniopomorskie & 31.75 \\
\hline
\end{tabular}

* Poland is divided administratively into 16 voivodeships.

It is clear that plantations located on agricultural lands are the most efficient-speaking in terms of production [16]. However, as such locations are limited and utilized for more demanding crops, it is necessary in Poland to reach for low-quality, devastated and degraded soil. Such land is collectively referred to as marginal land. These areas at a low cost (cost of soil type and quality verification) can be adopted and serve as plantations of fast-growing trees. Marginal lands are lands currently in agricultural use or classified in the agricultural land records as not suitable for the production of healthy food, due to unfavorable environmental and anthropogenic conditions, are qualified for a different use form. In Poland, the area of marginal lands reaches $2.3 \mathrm{MM}$ ha, which is equivalent to $16 \%$ of the agricultural lands. Approximately 1.7-MM ha (90\%) of those lands are very light, dry and barren sandy areas. The marginal lands include the unfertile parts of agricultural lands where production is not cost-effective due to unfavorable environmental conditions and erosion. These lands are located in Małopolskie Voivodeship and Podkarpackie Voivodeship and amount to 370,000 hectares. The lands of various quality class but chemically polluted account for 140,000 hectares, and degraded or mechanically transformed lands that lack humus accumulate to 50,000 hectares. Furthermore, the marginal lands include lands with unfavorable environmental territorial conditions. This group includes cultivated areas difficult to access or difficult to cultivate mechanically [56].

As an illustration of a recultivation process of devastated soil in Poland, a forestation of a part of a dumping ground in an open pit sulfur mine in Piaseczno near Tarnobrzeg City can be set as an example [57]. Between 1967 and 1969, black locust was planted in a space of $1.2 \mathrm{~m} \times 0.6 \mathrm{~m}$ on the slopes with unfavorable soil and untreatable agrotechnical (average slope of $60 \%$ ) ravines. The tree stands were not fertilized or cut. In 2009, the 42 -year-old tree stands were tested. It was calculated that the annual stand increment was $5.9 \mathrm{~m}^{3} \times \mathrm{ha}^{-1}$ on the north slope, $4.8 \mathrm{~m}^{3} \times \mathrm{ha}^{-1}$ on the southeast and $3.6 \mathrm{~m}^{3} \times \mathrm{ha}^{-1}$ on the south slope. These numbers are not high; however, the single purpose of planting black locust was, first and foremost, soil reclamation. The wood produced was a byproduct of the process. On the other hand, in such extremely unfavorable soil, the average annual increment of $4.8 \mathrm{~m}^{3} \times \mathrm{ha}^{-1}$ can be considered as a relatively high value, compared to the black locust average production capacity of $7.06 \mathrm{~m}^{3} \times \mathrm{ha}^{-1}$ per year [57]. Hybrid poplar 275 is a cultivar with low requirements for soil quality conditions capable of adapting to soils of different types. In Poland, there is a long tradition of growing poplar cultivar "Hybrid 275" (as a clone obtained from the $S$. Tacamahaca species cross $P$. maximowiczii $\times$ P. trichocarpa) $[42,58]$. 
Therefore, it can be treated as the most appropriate mean in the process of the reclamation of lands offering annual increments higher than black locust. Moreover, poplar has the ability to accumulate substantial amounts of cadmium, zinc, lead and copper. Thus, in the areas polluted with heavy metals, poplar may be used for bioremediation of the environment [59].

The predicted values are vectors of probabilities of transitions to alternative land uses and the transition of land uses and forest management type conditional on the biophysical and socioeconomic factors. Regardless of the data presented, it may have some limitations. The potential of plantation crops of fast-growing trees in agriculture depends on the availability of the lands, climate conditions and water supply, as well as the quality of soils [12]. However, plantations can contribute to the enhancement of biodiversity in intensively used landscapes with low habitat heterogeneity [55]. In addition, some recommendations have been already developed to further improve the habitat function of fast-growing tree plantations and to increase their contributions to farmland biodiversity, especially to plant species diversity (phytodiversity). This includes the cultivation of different tree species in small-scale units; the sectional harvesting of trees in order to establish a mosaic of different growth stages side by side and the integration of accompanying structures such as headlands, clearings or rides to provide additional open habitat elements. The knowledge in this area can be used to promote phytodiversity in agricultural landscapes, as they contain relatively high species numbers (of mainly common and adaptable species) and support distinct plant communities that differ from other farmland habitats.

The presented results are related with Polish lands. Due to the fact that the Polish wood sector is important for all the European region, the information in that area is necessary. In the other regions of Europe (or the world), due to different forms of land and forest ownership, as well as regulations, there are no applications to obtain the results. The specificities of the regions require analyses at the regional level. For example, research determining potential areas for the establishment of commercial forest plantations were performed for Mexico for Tabebuia rosea (Bertol.) DC. by using geographic information systems [60]. A land suitability evaluation was evaluated for two forest plantations, including oak (Quercus robur L.) and pine (Pinus sylvestris L.) in the northeast of Iran [61]. The study area involved an area of about $394 \mathrm{~km}^{2}$ with a total mainstream length of $35 \mathrm{~km}$. The relatively small area allowed for the assessment of the potential area for trees plantation, taking into account the climate, soil and terrain data. Similar research was conducted for the southern part of the USA [62]. Land resources potentially available for pine plantations were determined using matrices of land and forest-type changes conditional on the biophysical and socioeconomic factors and applying them to the available land and forest resources to forecast the dynamics of pine plantations [62].

\subsection{The Assessment of Potentially Available Quantities of Alternative Raw Material for the Wood Industry}

The estimated increment of poplar and larch on sown and forest lands is shown in Table 3. The calculations assume $5 \%$ use of the sown lands (i.e., 531,999 ha) and $5 \%$ of the forest land (i.e., 47,202 ha) and $100 \%$ coverage of the land with the poplar plantation, with the average increase in the tree stand thickness for the poplar about $25 \mathrm{~m}^{3} \times \mathrm{ha}^{-1}$. In the case of $50 \%$ capacity of the poplar plantation, the annual wood production is estimated as $7 \mathrm{MM} \mathrm{m}^{3}$. In the case of planting $50 \%$ of the land with larch and $50 \%$ with poplar, an assumed $50 \%$ capacity of the plantation should produce $5.63 \mathrm{MM} \mathrm{m}^{3}$ of wood per year.

From the data presented in Table 3, it was concluded that, when plantations cover $5 \%$ of sown areas and $5 \%$ of forest areas, the annual increase in large-sized wood may be from $8.11 \mathrm{MM} \mathrm{m}^{3}$ (100\% coverage with larch) to $14.48 \mathrm{MM} \mathrm{m}^{3}$ (100\% coverage with poplar). Considering the fact that, in 2015, the annual shortage of wood only for the wood-based panels industry reached the level of around 7.7-11.4 $\mathrm{MM} \mathrm{m}^{3}$ [33] by using the indicated areas, it will be possible to significantly reduce the deficit of raw wood material in Poland. 
Table 3. Data on the potential wood base from sown land and forest land.

\begin{tabular}{|c|c|c|c|}
\hline \multirow{4}{*}{ Annual Increase in the Tree Stand Thickness } & \multicolumn{3}{|c|}{ Cultivation Type/Plantation Coverage Level } \\
\hline & \multirow{2}{*}{$100 \%$ of Larch } & \multirow{2}{*}{$100 \%$ of Poplar } & \multirow{2}{*}{$\begin{array}{c}50 \% \text { of Larch } \\
\text { and } 50 \% \text { of Poplar }\end{array}$} \\
\hline & & & \\
\hline & \multicolumn{3}{|c|}{ from Sown Land (MM m ${ }^{3}$ per year) } \\
\hline $14\left(\mathrm{~m}^{3} \times \mathrm{ha}^{-1}\right)$ & 7.45 & - & 3.72 \\
\hline $25\left(\mathrm{~m}^{3} \times \mathrm{ha}^{-1}\right)$ & - & 13.30 & 6.65 \\
\hline \multirow[t]{2}{*}{ For $50 \%$ capacity $\left(\mathrm{MM} \mathrm{m}^{3}\right)$} & 3.72 & 6.65 & 5.17 \\
\hline & \multicolumn{3}{|c|}{ from Forest Land (MM $\mathrm{m}^{3}$ per year) } \\
\hline $14\left(\mathrm{~m}^{3} \times \mathrm{ha}^{-1}\right)$ & 0.66 & - & 0.33 \\
\hline $25\left(\mathrm{~m}^{3} \times \mathrm{ha}^{-1}\right)$ & - & 1.18 & 0.59 \\
\hline For $50 \%$ capacity $\left(\mathrm{MM} \mathrm{m}^{3}\right)$ & 0.33 & 0.59 & 0.46 \\
\hline
\end{tabular}

Lindegaard et al., [63] indicated that, with the intensification of the activities aimed at increasing the plantation areas of rapidly growing trees in Europe so far, each region has developed a number of recommendations for policymakers, public authorities and government agencies to support the development, production and use of biomass obtained from these types of crops for applications for energy and industrial purposes. It was pointed out that each region has many similarities regarding the restrictions on establishing and running fast-growing tree plantations. There is a need to educate farmers and policymakers about the multifunctional benefits of fast-growing tree plantations. In order to develop the market for planting fast-growing trees, more financial support is needed from regional and/or national authorities. Introducing targeted subsidies as an encouragement for growers could solve the problem of the lack of local supply chains. Haughton et al., [64] stated that promoting the plantation of fast-growing trees on agricultural land is important to increasing the landscape diversity and improving the ecosystem functions. Overall, fast-growing tree plantations are viewed positively by farmers to a limited extent, unless they receive the same benefits, subsidies and support that are offered to renewable energy providers. The relevant issue in this aspect also supports bureaucratic procedures at the regional and national levels. The role of scientists is also crucial in ensuring that there is clear and concrete evidence that planting fast-growing trees produces a range of environmental and socioeconomic benefits.

\section{Conclusions}

A constant supply of raw wood for the Polish market is a crucial matter for the Polish wood industry. Establishing fast-growing tree plantations would make it possible to obtain a supplementary source of lignocellulosic raw materials for wood-based panels production. Unlike traditional forestry based on natural or semi-natural forests, plantations offer a number of advantages, such as relatively short production cycles, as well as a possibility of producing raw material that meet specific requirements (for particular clients). Such wood may be produced in large quantities only thanks to plantations of vegetatively reproduced progeny from properly selected species. Moreover, the production of plantation woody raw materials may be located near end customers. Such and many other benefits have led to a noticeable worldwide development of this form of commercial wood production. In order to maintain a leading position in the Polish industry for the production of wood-based panels in the world, Poland must implement deep changes not only in the process of plantations creation but, also, in the legislation area, emphasizing how strategic creating a secondary source of raw materials is.

The analyzed data evidenced that the research conducted in Poland for several decades showing that the species with the highest productivity in plantations are poplar (mainly the cultivar "Hybrid 275") and, also, European larch (less popular in other European countries). Based on the presented research results, it can be concluded that, using only $5 \%$ of the 
sown area or $5 \%$ of the forest land and woody and bushy land, it is theoretically possible to obtain, respectively, 531,999 or 47,202 hectares of land for plantations of fast-growing trees. In the case of planting 50\% of these lands with larch and $50 \%$ with poplar, at a $50 \%$ capacity of the plantation, it will be possible to obtain nearly $6 \mathrm{MM} \mathrm{m}^{3}$ of wood per year. When the land allotted to plantations of fast-growing trees constitutes $10 \%$ of the sown area, permanent meadows and forest land and 30\% fallow land, uncultivated and other land, the potential area for plantations may reach approximately 1.52 $\mathrm{MM}$ ha. It was concluded that, using an estimated plantation area covering only $5 \%$ of the sown areas and $5 \%$ of the forest areas, the annual increase in large-sized wood may be from $8.11 \mathrm{MM} \mathrm{m}^{3}(100 \%$ coverage with larch) to $14.48 \mathrm{MM} \mathrm{m}^{3}$ (100\% coverage with poplar).

From a practical point of view, based on the obtained results, it can be said that, in Poland, plantations can be established on sown lands; forest lands and, partially, on areas under cultivation, permanent meadows and on fallow and idle lands. Plantations can be established by large companies through land leases, by farmers on their own lands and, also, by SFN FH on lands transformed by agricultural activity placed at their disposal under the provisions of the National Programme for the Augmentation of Forest Cover. Taking that into consideration, another conclusion can be made that such research plays a part in ensuring there is clear and concrete evidence in the field of the environmental and socioeconomic benefits of the cultivation of fast-growing tree plantations. Such a quantity of potential of the raw material makes it possible to eliminate the wood deficit existing in Poland as a crucial global producer of wood-based materials.

Author Contributions: Conceptualization, P.B.; methodology, P.B.; formal analysis, A.J. and A.L.; investigation, A.J., A.L., M.K. and M.M.; resources A.J., A.L., M.K. and M.M.; data curation, P.B., A.J., A.L., M.K. and M.M.; writing—original draft preparation, A.J. and A.L.; writing-review and editing, P.B., A.J. and A.L.; visualization, M.K. and M.M.; supervision, A.J. and A.L.; project administration, P.B. and funding acquisition, P.B. All authors have read and agreed to the published version of the manuscript.

Funding: This research was carried out under development project No. LIDER/002/406/L-4/NCBR/2013, financed by The National Centre for Research and Development.

Data Availability Statement: Not applicable.

Conflicts of Interest: The authors declare no conflict of interest.

\section{References}

1. EPF. Available online: www.europanels.org/facts--figures/market-information (accessed on 17 March 2021).

2. Respondek, T.; Adamowicz, M.; Wiktorski, T. Drewno-Strategiczny surowiec branży meblarskiej (Wood-A strategic raw material of furniture industry). In Drewno-Surowiec Strategiczny? (Wood-A Strategic Raw Material?); Strykowski, W., Gałecka, A., Pawłowska, J., Eds.; Instytut Technologii Drewna, Centrum Informacyjne Lasów Państwowych: Warsaw, Poland, 2012 ; pp. 57-64.

3. Boruszewski, P. Raw materials for the wood based composites industry. In Raw Materials and Particleboards-A Current Status and Perspectives; Boruszewski, P., Mamiński, M., Ružinska, E., Eds.; Warsaw University of Life Sciences-SGGW Press: Warsaw, Poland, 2012; pp. 5-20.

4. European Economic and Social Committee. Opinion of the European Economic and Social Committee on 'Opportunities and Challenges for a More Competitive European Woodworking and Furniture Sector' (Own-Initiative Opinion); European Parliament: Brussels, Belgium, 2011.

5. Strykowski, W. Czy drewno jest surowcem strategicznym? (Is wood a strategic raw material?). In Drewno-Surowiec Strategiczny? (Wood-A Strategic Raw Material?); Strykowski, W., Gałecka, A., Pawłowska, J., Eds.; Instytut Technologii Drewna, Centrum Informacyjne Lasów Państwowych: Warsaw, Poland, 2012; pp. 11-25.

6. Kelty, M.J. The role of species mixtures in plantation forestry. For. Ecol. Manag. 2006, 233, 195-204. [CrossRef]

7. Dimitriou, I.; Rutz, D. Sustainable Short Rotation Coppice-A Handbook; WIP Renewable Energies: Munich, Germany, 2015.

8. Baum, S.; Weih, M.; Busch, G.; Kroiher, F.; Bolte, A. The impact of Short Rotation Coppice plantations on phytodiversity. Landbauforsch. Vti Agric. For. Res. 2009, 3, 163-170.

9. Baum, C.; Leinweber, P.; Weih, M.; Lamersdorf, N.; Dimitriou, I. Effects of short rotation coppice with willows and poplar on soil ecology. Landbauforsch. Vti Agric. For. Res. 2009, 3, 183-196.

10. Mola-Yudego, B. Regional Potential Yields of Short Rotation Willow Plantations on Agricultural Land in Northern Europe. Silva Fenn. 2010, 44, 63-76. [CrossRef] 
11. Liesebach, M. Poplars and Other Fast Growing Tree Species in Germany: Report of the National Poplar Commission. 2016-2019; Thünen Working Paper, No. 141a; Johann Heinrich von Thünen-Institut: Braunschweig, Germany, 2020. [CrossRef]

12. Szostak, A.; Bidzińska, G.; Ratajczak, E.; Herbeć, M. Wood biomass from plantations of fast-growing trees as an alternative source of wood raw material in Poland. Drewno 2013, 56, 85-113. [CrossRef]

13. Xu, X.; Mola-Yudego, B. Where and when are plantations established? Land-use replacement patterns of fast-growing plantations on agricultural land. Biomass Bioenergy 2021, 144, 105921. [CrossRef]

14. Thoemen, H.; Irle, M.; Sernek, M. Wood-Based Panels: An. Introduction for Specialists, 1st ed.; Brunel University Press: London, UK, 2010.

15. Bielawska, K. Uprawy plantacyjne alternatywą? (Plantation crops as an alternative?). Głos Lasu 2009, 12, 6-8.

16. Zajączkowski, J.; Zajączkowski, K. Hodowla Lasu (Silviculture); Państwowe Wydawnictwo Rolnicze i Leśne: Warsaw, Poland, 2013.

17. Warmbier, K.; Wilczyński, A.; Danecki, L. Properties of one-layer experimental particleboards from willow (Salix viminalis) and industrial wood particles. Eur. J. Wood Wood Prod. 2013, 71, 25-28. [CrossRef]

18. Sean, S.T.; Labrecque, M. Use of short-rotation coppice willow clones of Salix viminalis as furnish in panel production. For. Prod. J. 2006, 56, 47-52.

19. Warmbier, K.; Wilczyński, A.; Danecki, L. Particle size dependent properties of three-layer particleboards with the core layer made from willow (Salix viminalis). Ann. Wars. Univ. Life Sci. SGGW For. Wood Technol. 2010, 71, 405-409.

20. Suchsland, O.; Woodson, G.E. Fiberboard Manufacturing Practices in the United States; Forest Products Research Society USDA Forest Service: Madison, WI, USA, 1991.

21. Chen, T.Y.; Wu, J.P. Studies on the manufacturing of particleboard from fast-growing tree species (IV-1)—Effect of particleboard density on the properties of the PMDI and UF glue bonded particleboard. For. Prod. Ind. 1993, 12, $72-88$.

22. Medved, S. Impact of wood species used in surface layer on density distribution of particleboard. Drewno 2007, 50, 17-26.

23. Irle, M.; Barbu, M.C. Chapter 1 Wood-based panels technology. In Wood-Based Panels. An introduction for Specialists; Thoemen, H., Irle, M., Sernek, M., Eds.; Brunel University Press: London, UK, 2010; pp. 1-94.

24. Habibi, M.R.; Hosseinkhani, H.; Mahdavi, S.; Sepidehdam, J. Effect of wood species on particleboard properties. Iran. J. Wood Pap. Sci. Res. 2011, 26, 58-71.

25. Boruszewski, P.; Borysiuk, P.; Mamiński, M.; Czechowska, J. Mat compression measurements during low-density particleboard manufacturing. BioResources 2016, 11, 6909-6919. [CrossRef]

26. Zaraziński, K.; Boruszewski, P. Analysis of the influence of particle and poplar fibres share on selected properties of particle-fibre bords. Ann. Wars. Univ. Life Sci. SGGW For. Wood Technol. 2020, 112, 22-31. [CrossRef]

27. Pazio, B.; Boruszewski, P. Analysis of the influence of larch fibers and particles on selected properties of fiber- and particleboards. Ann. Wars. Univ. Life Sci. SGGW For. Wood Technol. 2020, 111, 43-52. [CrossRef]

28. European Parliament. Communication From the Commission to the European Parliament, the Council, the European Economic and Social Committee and the Committee of the Regions. A new EU Forest Strategy: For Forests and the Forest-Based Sector; European Parliament: Brussels, Belgium, 2013.

29. State Forest Information System (SILP). (accessed on 17 March 2021).

30. Zajączkowski, K. Dobór odmian topól i wierzb do uprawy na plantacjach drzew szybko rosnacych (Selection of varieties of poplar and larch for plantations of fast-growing trees). In Elementy Genetyki i Hodowli Selekcyjnej Drzew Leśnych (Elements of Genetics and Selective Cultivation of Forest Trees); Sabor, J., Ed.; Centrum Informacyjne Lasów Państwowych: Warsaw, Poland, 2006; pp. 281-301.

31. Bradshaw, H.D., Jr.; Strauss, S.H. Breeding strategies for the 21st Century: Domestication of poplar. In Poplar Culture in North America; Dickmann, D.I., Isebrands, J.G., Eckenwalder, J.H., Richardson, J., Eds.; National Research Council Press: Ottawa, ON, Canada, 2001; pp. 383-394.

32. Strauss, S.H.; Brunner, A.M.; Busov, V.B.; Ma, C.; Meilan, R. Ten lessons from 15 years of transgenic Populus research. Forestry 2004, 77, 455-465. [CrossRef]

33. Brunner, A.M.; Li, J.; DiFazio, S.P.; Shevchenko, O.; Montgomery, B.E.; Mohamed, R.; Wei, H.; Ma, C.; Elias, A.A.; Van Wormer, K.; et al. Genetic containment of forest plantations. Tree Genet. Genomes 2007, 3, 75-100. [CrossRef]

34. Flachowsky, H.; Hanke, H.; Peil, M.V.; Strauss, S.H.; Fladung, M. A review on transgenic approaches to accelerate breeding of woody plants. Plant Breed. 2009, 128, 217-226. [CrossRef]

35. Strauss, S.H.; Raffa, K.F.; List, P.C. Ethics and Genetically Engineered Plantations. J. For. 2000, 98, 47-48.

36. Lang, C. Genetically Modified Trees. The Ultimate Threat to Forests; World Rainforest Movement and Friends of the Earth: Montevideo, Uruguay, 2004.

37. Gamborg, C.; Sandøe, P. Ethical considerations regarding genetically modified trees. In Forests and Genetically Modified Trees; El-Kassaby, Y.A., Prado, J.A., Eds.; The Food and Agriculture Organization of the United Nations (FAO): Rome, Italy, 2010; pp. 163-175.

38. Muhs, H.J. Regulation for genetically modified forest reproductive material moving in international trade. In Forests and Genetically Modified Trees; El-Kassaby, Y.A., Prado, J.A., Eds.; The Food and Agriculture Organization of the United Nations (FAO): Rome, Italy, 2010; pp. 227-235. 
39. Rowe, R.L.; Hanley, M.E.; Goulson, D.; Clarke, D.J.; Doncaster, C.P.; Taylor, G. Potential benefits of commercial willow Short Rotation Coppice (SRC) for farm-scale plant and invertebrate communities in the agri-environment. Biomass Bioenergy 2011, 35, 325-336. [CrossRef]

40. Rodriguez-Pleguezuelo, C.R.; Duran-Zuazo, V.H.; Bielders, C.; Jimenez-Bocanegra, J.A.; Perea-Torres, F.; Francia Martinez, J.R. Bioenergy farming using woody crops. A review. Agron. Sustain. Dev. 2015, 35, 95-119. [CrossRef]

41. Parmar, K.; Keith, A.M.; Rowe, R.L.; Sohi, S.P.; Moeckel, C.; Pereira, M.G.; McNamara, N.P. Bioenergy driven land use change impacts on soil greenhouse gas regulation under Short Rotation Forestry. Biomass Bioenergy 2015, 82, 40-48. [CrossRef]

42. Niemczyk, M.; Wojda, T.; Kaliszewski, A. Biomass productivity of selected poplar (Populus spp.) cultivars in short rotations in northern Poland. N. Z. J. For. Sci. 2016, 46, 22. [CrossRef]

43. Zajaczkowski, K.; Wojda, T. Plantacje topolowe w przyrodniczych warunkach Polski (Poplar plantations in the environmental conditions in Poland). Studia Mater. CEPL Rogowie 2012, 33, 136-142.

44. Zabielski, S. Plantacyjna Uprawa Drzew i Krzewów Szybko Rosnacych (Plantations of Fast-Growing Trees and Bushes); Akademia Rolnicza: Poznań, Poland, 1998.

45. Karp, A.; Shield, I. Bioenergy from plants and the sustainable yield challenge. New Phytol. 2008, 179, 15-32. [CrossRef]

46. GUS. Available online: https://stat.gov.pl/obszary-tematyczne/rolnictwo-lesnictwo/rolnictwo/charakterystyka-gospodarstwrolnych-w-2016-r-, 5,5.html (accessed on 31 March 2021).

47. Sajnóg, N.; Wójcik, J. Możliwości zagospodarowania gruntów marginalnych i nieużytków gruntowych w scalaniu gruntów (Possibilities of developing degraded and unculitivated lands in land consolidation). Infrastrukt. Iekologia Teren. Wiej. 2013, 2,155-166.

48. Cubbage, F.; Koesbandana, S.; Mac Donagh, P.; Rubilar, R.; Balmelli, G.; Olmos, V.M.; De La Torre, R.; Murara, M.; Hoeflich, V.A.; Kotze, H.; et al. Global timber investments, wood costs, regulation, and risk. Biomass Bioenergy 2010, 34, 1667-1678. [CrossRef]

49. Walker, J. Wood Quality: A Perspective from New Zealand. Forests 2013, 4, 234-250. [CrossRef]

50. Korhonen, J.; Toppinen, A.; Cubbage, F.; Kuuluvainen, J. Factors Driving Investment in Planted Forests: A Comparison between OECD and Non-OECD Countries. Int. For. Rev. 2014, 16, 67-77. [CrossRef]

51. Carle, J.; Vuorinen, P.; Del Lungo, A. Status and Trends in Global Forest Plantation Development. For. Prod. J. 2002, 52, 1-13.

52. GUS. Available online: http://stat.gov.pl/obszary-tematyczne/rolnictwo-lesnictwo/psr-2010/powszechny-spis-rolny-2010 -obszary-wiejskie,1,1.html (accessed on 16 March 2021).

53. ARMA. Available online: https://www.gov.pl/web/arimr/srednia-powierzchnia-w-2020r (accessed on 12 July 2021).

54. Grzegorzewska, E.; Burawska-Kupniewska, I.; Boruszewski, P. Economic profitability of particleboards production with a diversified raw material structure. Maderas. Cienc. Tecnol. 2020, 22, 537-548. [CrossRef]

55. Zitzmann, F.; Rode, M. Short-Rotation Coppice Managed According to Ecological Guidelines-What Are the Benefits for Phytodiversity? Forests 2021, 12, 646. [CrossRef]

56. Wójcik, J.; Balawejder, M.; Leń, P. Grunty marginalne, propozycje sposobów ich zagospodarowania w pracach scaleniowych w powiecie brzozowskim (Marginal lands, proposals for their management in the consolidating works in the District of Brzozów). Infrastrukt. Ekol. Teren. Wiej. 2014, 2, 399-410.

57. Węgorek, T. Warunki produkcji leśnej na skarpach zwałowiska zewnętrznego po kopalni siarki w Piasecznie w aspekcie pozyskania drewna opałowego (The conditions of forest production on scarps of the externalwaste bank after sulphur mine in piaseczno in the aspect of firewood logging). In Tereny Zdegradowane i Rekultywowane-Możliwości ich Zagospodarowania (Reclaimed and Degraded Areas-Possibilities of Their Development); Stankowski, S., Pacewicz, K., Eds.; P.P.H. Zapol Dmochowski, Sobczyk Sp. j.: Szczecin, Poland, 2009; pp. 219-229.

58. Niemczyk, M.; Wojda, T.; Kantorowicz, W. Przydatność hodowlana wybranych odmian topoli w plantacjach energetycznych o krótkim cyklu produkcji. Sylwan 2016, 160, 292-298.

59. Kabała, C.; Karczewska, A.; Kozak, M. Przydatność roślin energetycznych do rekultywacji i zagospodarowania gleb zdegradowanych (Energetic plants in reclamation and management of degraded soils). Zesz. Nauk. Uniw. Przyr. Wrocławiu Rol. 2010, 576, 97-118.

60. Muñoz-Flores, H.J.; Castillo-Quiroz, D.; Castillo-Reyes, F.; Sáenz-Reyes, J.T.; Avila-Flores, D.; Rueda-Sánchez, A. Potential Areas for Commercial Timber Plantations of Tabebuia rosea (Bertol.) DC. in Michoacan, Mexico. Open J. For. 2017, 7, 48-57. [CrossRef]

61. Gholizadeh, A.; Bagherzadeh, A.; Keshavarzi, A. Model application in evaluating land suitability for OAK and PINE forest plantations in Northeast of Iran. Geol. Ecol. Landsc. 2020, 4, 236-250. [CrossRef]

62. Zhang, D.; Polyakov, M. The geographical distribution of plantation forests and land resources potentially available for pine plantations in the U.S. South. Biomass Bioenergy 2010, 34, 1643-1654. [CrossRef]

63. Lindegaard, K.N.; Adams, P.W.R.; Holley, M.; Lamley, A.; Henriksson, A.; Larsson, S.; Von Engelbrechten, H.G.; Lopez, G.E.; Pisarek, M. Short Rotation Plantations Policy History in Europe: Lessons from the Past and Recommendations for the Future. Food Energy Secur. 2016, 5, 125-152. [CrossRef]

64. Haughton, A.J.; Bohan, D.A.; Clark, S.J.; Mallott, M.D.; Mallott, V.; Sage, R.; Karp, A. Dedicated biomass crops can enhance biodiversity in the arable landscape. GCB Bioenergy 2015, 8, 1071-1081. [CrossRef] [PubMed] 